\title{
The Spirit of God, or is it?
}

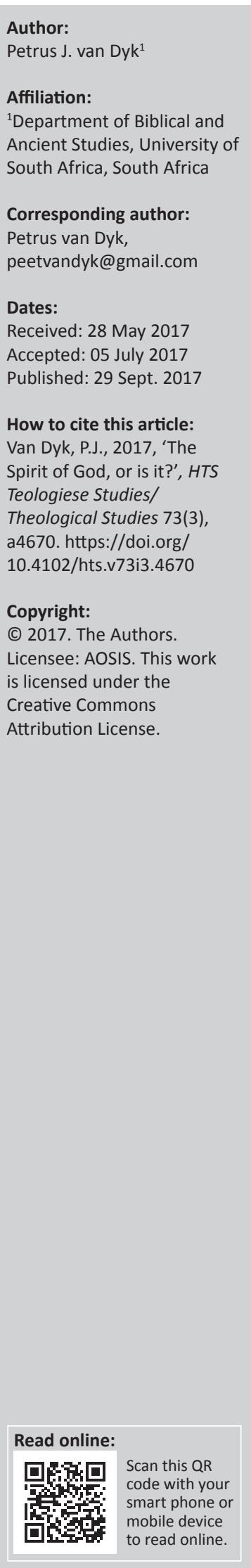

When the modern reader and the ancient biblical text do not share the same cosmology, this may lead to gross misinterpretation of the text, or to a reduction in meaning. The term מיהלא חור [spirit of God] is used as an example to illustrate the possibility of such misinterpretation. It is argued that the term should be viewed as a case of polysemy (words with multiple senses, which are not trivially related to one another) and thus form a rich complex of meaning. This implies that the so-called fallacy of 'illegitimate totality transfer' does not apply to polysemous words, because all the senses are activated in every context. The senses of spirit, breath and wind should therefore not be viewed as alternative meanings (as one would do in the case of homonyms), but as contributing to a rich complex meaning, which makes logical sense within the magico-mythical cosmology of the Old Testament.

\section{Introduction}

One of the major ways in which the term רוח אלהים (spirit of God) in the Old Testament (OT) is being misinterpreted results from the fact that the magico-mythical cosmology ${ }^{1}$ of the OT is habitually overlooked or misconstrued by scholars. This is often an unconscious process when exegetes, as a matter of habit, fall back onto their default modern (i.e. post-Renaissance and post-Enlightenment) frame of reference. Or to use Gadamer's terminology: when exegetes neglect the horizon of the text in favour of the horizon of the modern reader (Gadamer 1982). The unfortunate result, when mistakenly assuming that the OT shares our modern cosmology, is that the 'otherness' of the OT text is not sufficiently recognised (Pickering 1999). I therefore want to argue that a consistent cosmological approach to the OT should be implemented as the overarching model for biblical hermeneutics. Such an approach would take the magico-mythical cosmology of the OT seriously by consistently using it as the frame of reference for the biblical text, rather than doing it on an ad hoc basis (Van Dyk 2017).

The purpose of this article is to provide an example of the kind of problems that can ensue in biblical exegesis if such a cosmological approach is not followed consistently. For this purpose, the OT term רוח אלהים (spirit of God) will be explored (merely as an example) to illustrate the reduction in meaning that can take place when exegetes and translators are 'forced' to choose between so-called alternative meanings for the term רוח אלהים. It is therefore a much bigger hermeneutical problem that I want to address, rather than just a 'small matter of translation'.

\section{Translation problems and the possibility of polysemy}

The term רוח אלהים occur many times in the OT and have been interpreted and translated in various ways, depending on the context in which they occur. These variant translations agree with the 'acceptable' lexical fact that the Hebrew word can either mean spirit, breath or wind and that אלהים can in some instances be used as a superlative (Moscati 1947:306). In the past, most translators and scholars therefore regarded the possible senses of as alternative meanings and felt obliged to choose between these meanings when interpreting or translating the OT text.

The lack of agreement among scholars when choosing the most appropriate meaning for the term within a specific context strongly suggests that a choice between alternative senses for a term is not always as easy as it may appear at first glance. This lack of agreement can best be illustrated by considering the history of translation of Genesis 1:2. The text reads as follows:

And the earth was without form and void and darkness was on the face of the deep. And the spirit of God moved/hovered on the face of the waters.

1.A more correct and complete term would be a 'magico-religious mythical cosmology', but such a triple term would be too cumbersome to use. The prefix 'magico' will therefore be used to refer to both personal and non-personal (i.e. magical) forces. The term also implies that mythology is closely linked to cosmology and that mythology should be defined in terms of cosmology. 
Through the centuries, at least five possible translations were considered for the term - mostly determined by dogmatic reasons. The following are examples:

1. 'Spirit of God' (uppercase 'S': referring specifically to the New Testament concept of the Holy Spirit). See, for example, KJV, RSV, NIV, NAS and Luther's German translation;

2. 'spirit of God' (lowercase 's': referring to God's spirit in general). See DRA; JPS and Tanakh;

3. 'breath of God'. This choice was seldom chosen by English translations, but see Alter (1996:3);

4. 'wind of God'. See NRSV, NRSVA and CEB;

5. 'mighty wind'. That is, when אלהים was interpreted as a superlative. See NABRE, EXB, Targum Onkelos and most Jewish interpreters, as well as scholars such as W.F. Albright (1924:363-369) and Speiser (1964:3).

Some English translations recognised the fact that the term poses a translation problem and therefore retained a transliteration of the Hebrew word ruach (e.g. OJB, DRA), while VOICE translated it with the double term 'God's spiritwind'.

Before further exploring the OT term רוח אלהים, the problem with binary logic firstly needs to be addressed and secondly the semantic concept of polysemy should be introduced as a possible alternative to the concept 'illegitimate totally transfer', which has in the past few decades been very popular in biblical semantics (Barr 2004; Wallace 2014).

\section{The restrictive idea of binary logic}

When going along with Aristotle's binary logic (or the idea of bivalence), it is assumed that a statement can either be true or it must, by logical necessity, be false (Kosko 1994:23). Binary logic therefore assumes a black and white world of opposites with the implication that one must choose between the two opposites or alternatives. Within semantics, binary logic has been applied in such a way that in cases where a word has different potential meanings or senses, the interpreter or translator was obliged to choose between these meanings, because they were viewed as alternatives - implying that only one meaning can be correct in any given context. This view of semantics is especially advocated by semanticists of the 'truth-conditional flavour' (Vicente 2015).

These assumptions of binary logic have further been formalised in biblical semantics by the proposed fallacy of 'illegitimate totally transfer'. According to this fallacy, it is an error to assume that the total history of a term as well as the sum of all its possible meanings are simultaneously present whenever a word is used (Barr 2004; Wallace 2014). There is little doubt that this concept of illegitimate totally transfer is helpful in many cases to prevent improper semantic conclusions, for example, when a word's meaning changed with time. The problem is, however, when the concept of illegitimate totality transfer is absolutised by implying that it applies in all circumstances - which is assumed within binary logic. It is then that it becomes a problematic concept, which can cause an unwanted reduction in meaning when dealing with a rich complex polysemous term.

Binary logic has been criticised by post-Structuralist philosophers such as Derrida, who suggested that we should deconstruct westernised thinking that tends to construct everything in terms of binary opposites, where one term is always given preference over its opposite (Derrida \& Bass 2002:351-370). Binary logic has further been criticised by the field of fuzzy logic for its lack of accuracy, that is, by forcing reality into alternative black and white categories without considering the possibility of various shades of grey (Kosko 1994:3-17).

When binary logic and its close associate, illegitimate totally transfer, held sway in biblical semantics, this practice of choosing between alternative meanings seemed to be quite reasonable. However, in the light of the convincing criticism of binary logic by the field of fuzzy logic (Kosko 1994:3-17), the obligatory choice between so-called alternative meanings has become questionable in at least some (although not in all) cases.

If it is accepted that binary logic does not always apply, it opens the door for the possibility of polysemy in the field of semantics (Falkum \& Vicente 2015; Fillmore \& Atkins 2000; Vicente 2015).

\section{Polysemy}

It is especially cognitive linguists who use the concept of polysemy in semantics. The term can either be used in a broader sense, referring to all words with multiple meanings (Noegel 1995:33) or in a narrower sense as referring only to words where the different senses are NOT trivially related. Biblical scholars have used it mostly in its broader sense, for example, when studying Janus parallelisms in the book of Job (e.g. Noegel 1995). ${ }^{2}$ In this article, I will use polysemy only in its narrow sense.

The important consequence of the narrow concept of polysemy is that it does not force the interpreters or translators into a situation where they must choose between alternative senses for a word, as proposed by binary logic. Vicente (2015) describes narrow polysemy as:

... the phenomenon where a term has different but non-trivially related meanings or senses (usually all of them having the same status with respect to their 'being the meaning of the word'). (p. 55)

In contrast to polysemy, the meanings of homonyms are trivially related to one another. For example, the English word 'pole' may either refer to a long, slender piece of wood, the north and south poles or to an inhabitant of Poland, with none of the senses being obviously related. Fillmore and

2.Janus (or two-faced) parallelism is a special kind of sophisticated wordplay in poetry, where a word with multiple meanings is used in the middle stich of poetry, while the where a word with pultiple the preceding stich anticipated the one meaning and the last stich refers to a second alternative meaning. However, in all the cases of Janus parallelism in the book of Job, the words with a double meaning are not examples of polysemy (in the narrower sense), because the alternative meanings are not related to one another and in some cases may even have been derived from entirely different roots (Noegel 1995:37). 
Atkins (2000:351-370) suggested that polysemes are characterised by three elements:

1. the different senses of polysemes have a central origin;

2. the senses are linked in such a way that they form a network of meaning; and

3. understanding the 'inner' (or focal) sense contributes to the understanding of the 'outer' senses.

The concept of polysemy therefore introduces the idea of multifaceted words with rich complex meanings, which should never (or at least not always) be reduced to a single sense.

According to scholars, the senses of a specific polyseme may either be stored as one presentation (while homonyms are stored as different presentations), or it may be a 'rich presentation which makes all senses of the polyseme available' (Vicente 2015:54-56). What is critical in the case of polysemy is that the different meanings do NOT compete for activation (as is the case with homonyms), but polysemous senses prime each other in such a way that each sense facilitates access to the others (Vicente 2015:55). This does not imply that all senses of a polyseme are equally activated, but rather that one sense may be highlighted (within a specific context), while the other senses will be less activated. Linking up with Fillmore and Atkins's view of polysemous words, one can further say that the meaning of a polysemous word is constructed not only from the inner sense of the word but is constructed in such a way that the outer senses (which form part of the larger network of meaning) contribute (although to a lesser extent) to the rich complex meaning of the polyseme in any given context.

One of the ways in which the senses of polysemous words can be linked to one another is via the cognitive framework of a cosmology, where they may form part of a larger integrated concept or idea. For example, in the theology of Heliopolis (in ancient Egypt), the physical manifestations of the gods Shu and Tefnut were dry air and moist air, respectively. The Egyptians therefore made no sharp distinction between these gods and the air or wind - a form of pantheism (Botterweck, Ringgren \& Fabry 2004:371). Viewed from the ancient Egyptian perspective (cosmology) the words 'Shu' and 'Tefnut' would therefore be a case of polysemy, because these words would never refer to either the air or the gods, but always to both (i.e. both senses are activated). However, if this inseparable link between air and gods was unknown to us, because of our modern cosmology, we may incorrectly have assumed they are homonyms (rather than a case of polysemy). We may then incorrectly have regarded the two senses as alternative senses, referring either to the air or to the gods, depending on the context. This example begs the question if the OT term רוח אלהים may be a similar case of polysemy, but may not have been recognised as such because within our modern cosmology we would make an absolute distinction between wind, breath and spirit (and may hence incorrectly assume no logical link exist between them) - see later.
The reasons why the term רוח אלהים may not previously have been recognised as a possible example of a polysemous term may be twofold: (1) because the idea of polysemous terms may have been swamped by the concern to avoid the socalled 'fallacy' of illegitimate totality transfer; and/or (2) because exegetes may habitually have fallen back onto their default modern scientific frame of reference (cosmology), which prevented them from recognising this case of polysemy. That is, they failed to realise that within the magico-mythical cosmology of the OT, the different senses of the term may not be alternative meanings, but may form part of a larger rich complex of meaning.

Before considering the possibility of interpreting the term as a polysemous term, it is necessary to briefly explore the relationship between spirit, breath and wind, as perceived within the Ancient Near East and other magicomythical cosmologies.

\section{Spirit, breath and wind in magico- mythical cosmologies}

Typical of pre-scientific cosmologies (including the OT) was the spiritualisation and personalisation of the whole cosmos (i.e. animism), which assumed that all living things have an indwelling spirit (Tylor 2010). The reverse side of this belief is that all spirits or forces have a physical manifestation. In contrast to Platonic dualism, an absolute distinction between the physical and spiritual was therefore absent in these magico-mythical cosmologies. Within a magico-mythical cosmology, spiritual and physical aspects were perceived as two sides of the same coin. This inter alia implies that spirits or magical forces manifest themselves in and through physical phenomena. For example, in Exodus 7-10 and in Exodus 14:16, Aaron's and Moses's rods were endowed with miraculous/magical powers (Klutz 2003). Within a magicomythical cosmology, this link between the physical and spiritual worlds is a basic tenet that cannot be violated.

Linked to the ancient notion within animism that all spirits manifest themselves in a physical way, was the idea that the breath of a person was the physical manifestation of that person's spirit. Within magico-mythical cosmologies, this idea made perfect sense because life without breath or without a spirit was inconceivable (Gaster 1981). This inseparable link between breath and spirit is demonstrated by the fact that when humans die, they 'blow out' their spirit with their last breath. This logical link between breath and blood and spirit and life is confirmed by the Ugaritic notion that '... when the blood of a person is poured out, life (nps) departs through the nostrils (' $p)$, like a breath $(r h)$ or smoke $(q t r)^{\prime}$ (Botterweck et al. 2004:369).

In addition to this logic of animism, is the semantic argument: In the ancient world and in pre-scientific cultures (i.e. magicomythical cosmologies), the same word was typically used for spirit, breath and air or wind. For example, in classical Greek, the word $\pi v \varepsilon v \mu \alpha$ could mean spirit, breath or wind

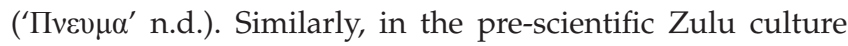


(South Africa), the word 'umoya' can be translated with breath, air, wind, spirit, soul or life (Oosthuizen 1967:57). It should further be noted that this close link between breath, wind and spirit is also evident in other world religions such as Islam, Buddhism and Taoism (Edwards et al. 2006:136).

Another indication of the inseparable link between spirit and breath in many pre-scientific African cultures is the fact that spiritual healing is often associated with holistic transformations, which are related to 'deep breathing' (Edwards et al. 2006:135). In practice, this belief implies that the spirit can be healed or cleansed by either deep breathing or by a traditional healer blowing over a troubled patient.

This curious fact, that even across cultures the same word is used to denote spirit, breath and wind, strongly suggests that the word may signify one undifferentiated concept within magico-mythical frames of reference, rather than three alternative concepts, as would be assumed by our modern scientific frame of reference. In all the above-mentioned cultures and languages, the word for spirit-breath can therefore be described as a case of polysemy.

But where does wind logically fit into this picture? Within our modern scientific and a-religious cosmology, wind is perceived as a completely natural phenomenon, caused by meteorological conditions. This scientific perception of the wind thus differs fundamentally from what wind was perceived to be within a magico-mythical cosmology.

In contrast to our scientific cosmology, wind was often perceived in magico-mythical cosmologies not as a natural phenomenon (Botterweck et al. 2004:381), but as something of supernatural origin and often as the breath of God. This is congruent with the spiritualisation of the whole cosmos within such cosmologies. Both breath and wind involve the movement of air. From this observation, it was but a small logical step (within a personalised and spiritualised mythical cosmology) to link the wind with God's breath-spirit.

The association between the gods and wind was indeed very close in ancient mythologies. For example, in ancient Mesopotamia, the god Enlil was the lord of breath or wind, while the god Marduk was said to command the four winds (Olmsted n.d.). Similarly, in ancient Egypt, the god Shu was regarded as the god of wind and air, while in Canaanite religion, Baal was depicted as a storm god, which included his command of the wind. When the wind was blowing, it was therefore seen as a deliberate act of the god, that is, as the forceful expelling of the god's breath. Even in those cases where the breath of the god is not explicitly mentioned, it may have been implied, especially in the case of a strong storm wind. It can therefore be concluded that the three senses of breath, spirit and wind were linked in magicomythical cosmologies and that this link was neither trivial nor accidental, but, as argued above, were inseparably linked in the cosmology of the Ancient Near East and in other magico-mythical cosmologies.

\section{Creation, wind and the primeval flood}

The link between the spirit-breath of god and wind in ancient cosmologies had very specific consequences of how creation was perceived within such cosmologies. Because the spirit of the god was perceived as a creative force and the breathwind was the physical manifestation of the god's spirit, it goes without saying that wind was also perceived as a creative force - intrinsically linked to creation and the primeval flood (Freedman 1996:12). In the Ancient Near East cosmology, 'creation often begins with that which emerges from the waters ...' (Gunkel 1966:103; Walton 2009:31) and frequently linked to this image was the presence of wind (always associated with a god). For example, in Ancient Egypt the Story of Re depicted creation as follows:

In the beginning, before there was any land of Egypt, all was darkness, and there was nothing but a great waste of water called Nun. The power of Nun was such that there arose out of the darkness a great shining egg, and this was Re. Now Re was allpowerful, and he could take many forms. His power and the secret of it lay in his hidden name; but if he spoke other names, that which he named came into being. 'I am Khepera at the dawn, and Re at noon, and Atum in the evening', he said. And the sun rose and passed across the sky and set for the first time. Then he named Shu, and the first winds blew; he named Tefnut the spitter, and the first rain fell. Next he named Geb, and the earth came into being; he named the goddess Nut, and she was the sky arched over the earth with her feet on one horizon and her hands on the other. ('Story of Re' n.d. [author's own italics])

For our purposes the most important points to note from this narrative are the following:

1. Before the creation of the ordered cosmos, a wasteland of water (primeval flood, or Nun) existed and it was covered in darkness.

2. Directly after the god Re created Shu (the god of air/ wind) the first winds blew - apparently over the primeval flood, because that was all that existed at the time.

3. After Shu, the rest of the tri-tier cosmos, namely the elemental gods were created: First the god Geb, whose body formed the dry ground or earth disc, then the goddess Nut, whose body formed the firmament or heavenly dome, while the dome was held up in the sky (supported) by Shu. In Egyptian creation, a very close connection between the god Shu, the wind and the primeval flood is therefore suggested.

This connection between a god, wind and primeval flood is also shared by the Mesopotamian creation narrative (Enūma eliš). In the Enūma eliš, the primeval flood (Tiamat) also predated the creation of the cosmos. On the Fourth Tablet of the myth, we learn that the champion of the gods, Marduk, prepares for battle against the chaotic forces of Tiamat. For this purpose, he started to arm himself, inter alia with the wind:

42 And [Marduk] stationed the four winds that no part of her [Tiamat] escape.

43 The South Wind, the North Wind, the East Wind, the West Wind, 
44 He put beside his net, winds given by his father, Anu. 45 He fashioned the Evil Wind, the Dust Storm, Tempest,

46 The Four-fold Wind, the Seven-fold Wind, the Chaosspreading Wind, the ... Wind.

47 He sent out the seven winds that he had fashioned,

48 And they took their stand behind him to harass Tia-mat's entrails.

A few lines later, when Marduk and Tiamat confronted each other in battle, we learn that Marduk used a net and the winds to capture Tiamat and render her helpless:

- 95 Be-1 spread out his net and enmeshed her;

- 96 He let loose the Evil Wind, the rear guard, in her face.

- 97 Tia-mat opened her mouth to swallow it,

- 98 She let the Evil Wind in so that she could not close her lips.

- 99 The fierce winds weighed down her belly,

- (Lambert 2007:15-59)

After Marduk rendered Tiamat helpless, he killed her and split her body into two parts to create the earth disc and the heavens (firmament) from them. From these sections of the Enūma eliš, one can highlight the following aspects:

1. The winds were closely associated with the storm god Marduk.

2. In the events leading immediately up to the creation of the cosmos, the wind (sent by Marduk) blew over the primeval flood (Tiamat) and disturbed her entrails.

3. The wind facilitated the creation of the cosmos by overpowering the chaotic waters of Tiamat.

Although the wind was not explicitly linked with the god's spirit or breath in the Egyptian and Mesopotamian creation accounts above, the creative force of the wind and its connection to the gods are clearly present. Within an animistic frame of reference, the wind, like the earth disc and the heavenly dome, were not seen as impersonal elements of the cosmos, but as the physical manifestations of various gods.

Conclusion: The above discussion strongly suggests that in magico-mythical cosmologies, such as the Ancient Near East, the word used for spirit-breath-wind is a case of polysemy and that these senses of the word should not be seen as alternative meanings from which the reader should choose one, depending on the context. It was further argued that the creative force of the god was closely associated with its spirit and that the presence of wind (the god's spirit-breath) during creation fitted this mythical assumption.

The last question that needs answering is if the OT concept of רוח אלהים may also be an example of polysemy and if translators and exegetes should therefore NOT choose between alternative meanings, but rather see the concept as a rich complex term with all senses being activated in different contexts.

\section{The term רוח אלהים in the OT}

Two main criteria can be used to argue that (like in other Ancient Near Eastern cosmologies) the OT רוח אלהים term is a case of polysemy:

1. Semantic argument: If within the biblical cosmology, the same word was used (like in other magico-mythical cosmologies) for spirit, breath and wind.

2. Insufficiency of a single sense: If it can be shown that one sense of the concept is insufficient to express its richness in meaning in at least some contexts.

\section{Semantic argument}

As was suggested earlier when exploring the various translations of Genesis 1:2, it is accepted by all Hebrew lexicons that the same Hebrew word רוח is used in the OT with the senses of spirit, breath and wind, as well as for related senses such as breeze, wind direction and in some cases may also refer to an emotional state, for example, anger or strife (e.g. Ex 6:9; Jdg 8:3; 9:23) (Botterweck et al. 2004; Brown et al. 2006; Köhler, Baumgartner \& Stamm 1996). The same root רוח is also used in all West Semitic languages with the same possible meanings and it has been suggested that it may be a case of an onomatopoetic word, imitating the sound of breathing. As a verbal noun, probably based on the infinitive, it thus denotes the action of blowing or respiration (Botterweck et al. 2004:368; Köhler et al. 1996). This may suggest that the 'inner' (prototypical) sense of the word is 'breath', with the senses of spirit and wind being derived from it.

In most cases, the lexicons present the senses as alternative meanings for the word, implying that the reader should choose between them. For example, Botterweck et al. (2004:373) suggest that one can distinguish between the meanings 'wind' versus 'breath, spirit', although they admit that it is not always possible to draw a clear line between them.

The wide variety of genres and texts, dating from different historical eras, in which different senses of the word רוח occur, suggest that a specific sense of the word was not favoured in any specific era, or by a certain genre (e.g. by poetic or prophetic texts) (see Botterweck et al. 2004:373).

It can therefore be argued that while the OT has the same word for spirit, breath and wind (like in other magicomythical cosmologies), this could hardly be accidental and could only be explained if the OT assumed the same logic as other magico-mythical cosmologies, which linked physical manifestations with spiritual phenomena.

\section{Insufficiency of a single sense}

The insufficiency of a single sense to express the complexity of the concept רוח אלהים in the OT is suggested by the explicit link that is made between God's breath and the wind. 


\section{The wind as God's breath}

The explicit association between the wind and God's breath is nowhere spelled out more clearly than in Exodus 15:8 and 10. Verse 8 literally reads: 'And through the רוח of your nose the waters piled up' and in verse 10 we read: 'You blew with your רוח and the sea covered them'. In these verses, the reference to 'nose' and 'blowing' indicates that the author is referring to God's breath, while the effect on the waters clearly refers to the effect of a strong wind blowing over them. The same image is presented in 2 Samuel 22:16, where YHWH is portrayed as an angry storm God and it is said that the 'blast of God's breath from his nostrils exposed the valleys of the sea and laid bare the foundations of the earth' (also see Psalm 135:7).

In Deutero-Isaiah (verse 40:7), the effect of a scorching desert wind is pictured by saying that the grass withers and the flowers fall off when God blows over them (also see Hs 13:15 and Job 15:30, where it is stated that unrighteous people will be destroyed by the breath of God's mouth).

Although God's breath (from his mouth or nostrils) and the wind are not explicitly linked in other contexts, these texts nonetheless clearly spell out that the wind comes from God. In Genesis 8:1, it is stated that the flood ended when '... God let passed (עבר) רוח over the earth and the waters receded'. Isaiah 59:19 also paints a picture of YHWH's רוח 'driving along' a rushing stream and in Numbers 11:31 YHWH let a go forth and it blew quails into the camp of the Israelites. Similarly, in 1 Kings 18:45, God sends a rain storm and causes a wind to blow, while in Psalm 107:25, God's word (and therefore his mouth) is linked to the stirring up of a storm wind, which caused high waves on the sea. In Zechariah 6:5, it is described how the four winds of heaven go forth before God.

In Ezekiel 8:3, the prophet is lifted up (נש:א) by the רוח of God so that he was elevated between the earth and the heaven. This image most probably suggested that the prophet was 'blown' into the air by God's breath-wind in the same way that the waters of the sea were contained in Exodus 15:8, 10 and 2 Samuel 22:16.

One can therefore conclude that (like in other magicomythical cosmologies) the two physical senses of the Hebrew concept רוח אלהים (i.e. breath and wind) were sometimes explicitly linked in the OT and in many other cases were closely associated with God.

\section{Breath and spirit}

The association between God's breath and its ability to make humans and animals to come alive (i.e. endowing them with a spirit) is suggested in the Yahwist's creation narrative in Genesis 2:7. Although the term רוח is not used in Genesis 2:7, but its synonym 'soul' (נפש ) the text states that man became a living soul when YHWH blew (נפח) the breath (נשמה) of life into his nostrils (Botterweck et al. 2004:386). This implies that humans only became alive after their souls was blown into their nostrils by God (also see Lamentations 4:20). This close association between breath and spirit is further supported by the notion in Genesis 7:22, where the term נשמת־רוח [the breath of the spirit] is used to describe all living beings (including animals).

In Job 33:4, we read the following: 'The רוח־אל has made me, the נשממה [breath] of the Almighty made me alive'. Placing נששמה abreath] in parallelism, attests to the fact that the two words were regarded as synonyms. The fact that being alive was not only seen in terms of the physical presence of breath but also reckoned with something supernatural, like the presence of a spirit or soul, is suggested by the fact that only God's breath could create life and the fact that the OT emphasises the fact that the spirit-breath of all living beings belongs to God and is a gift from him without which people and animals cannot be alive (e.g. Gn 6:17; 7:15, 22; Ezk 37:5-6, 8-10, 14; Eccl 3:9; Ps 78:39; 104:29-30; Job 34:14, 15; Is 38:16).

The fact that the term רוח does not merely refer to the physical breath of a person but also to the spirit is inter alia demonstrated by the fact that the רוז of God was closely associated with the ability to prophesy (sometimes including a state of ecstasy). In cases where רוח is linked to God and more specifically to the prophetic spirit, the sense of the word goes beyond the mere physical and is then mostly translated with 'spirit' (e.g. Nm 11:17, 25, 26, 29; 1 Sm 10:6, 10; 16:15 19:20, 23; Hs 9:7; Mic 3:8).

\section{Wind and spirit}

In cases where the creative and supernatural effects of the wind is stressed, this may suggest that the OT authors did not only think of a 'natural' wind but also had in mind the 'supernatural' creative effects of a spirit, for example, when the creative effect of the wind is emphasised, like in the Egyptian and Mesopotamian creation narratives.

The situation painted by the Priestly author in Genesis 1:2 (immediately before creation) and at the end of the flood ( $\mathrm{Gn}$ $8: 1$ ) (which was in a sense an un-creation and re-creation of the cosmos) (see Blenkinsopp 2011), reveals some striking similarities with the Egyptian and Babylonian cosmogonies. Genesis 1:2 reads:

And the earth was without form and empty (תהו ובהו) and darkness (חשך) was over the face of the deep/primeval flood (תהום) and the spirit-wind of God (רוח אלהים) moved/hovered (רחף) over the face of the waters. (p. 34)

The image painted by the text can be summarised as follows:

1. The earth disc (ארץ) or dry ground did not yet exist (it was without form and empty - תהו ובהו).

2. Darkness (חשך) was over the surface of the primeval flood (תהום). Although the Hebrew word תהום could not have been taken from the Babylonian (which did not have an ' $h$ ') it could have been influenced by the Ugarit word (with the same root), which referred to both the salt and sweet water of primeval flood (Van Selms 1967:23).

3. The רוח אלהים moved/hovered (רחף) over the waters of the primeval flood. 
Freedman (1996:10-11) rejects the notion that אלהים is used as a superlative in Genesis 1:2, pointing out that in Genesis 1:1 and 3, the word אלהים is used in its ordinary sense to refer to God, making it unlikely that it is a superlative in Genesis 1:2. The word is also used only in poetic texts as a superlative, or in prose texts when it qualifies intangible things or qualities (i.e. not the wind). Although he argues that Genesis 1:2 was demythologised, he nonetheless accepts the fact that the three terms תשך have definite mythological undertones (Freedman 1996:13). Contrary to Freedman, Gunkel (1966:103) accepted that the description of the chaotic primeval situation before creation in Genesis 1:1-2 was 'eine wahre mythologische Schatzkammer'.

Within a mythological frame of reference, one may have expected the wind of God to be present in Genesis 1:9 (when God separated the waters below from the waters above), but this is not the case. The image of a creative wind of God, blowing back the waters after the flood, is, however, present in Genesis 8:1b where we read: '... and God let pass (עבר) a רוח over the earth and the waters receded'. After the destruction (un-creation) of the world by the flood, the world is in a sense re-created or restored, and a wind from God is instrumental in subduing the waters (Blenkinsopp 2011). This may suggest that the wind was also viewed as a creative force, like in other Ancient Near Eastern cosmogonies: The image of רוח therefore includes but also goes beyond the sense of a physical wind only but includes the notion of God's spirit (Freedman 1996:13).

The verb רחף used by the Priestly author to describe the action of the wind is unusual. The OT uses nine different verbs to describe the movement of air, but the verb רחף is used only in this case. Some commentators tried to link the word to the mythological concept of a world egg, which hatched at the beginning of creation and thus translated the word with 'brooding' (Gunkel 1966:102; Skinner 1930:19; Von Rad 1972:47-48), but this idea was rightly rejected by Westermann (1976:148). In both the OT and in Ugaritic, the word usually describes the movement of a bird, that is, with the notion of stir, glide or hover (Freedman 1996:10; McClellan 1934:526). This would suggest that the verb refers to personal or animated action rather than an impersonal action. Within the prose text of the Priestly creation narrative, it is unlikely that this is a case of poetic personalisation of the wind. The verb should therefore rather be interpreted literally, as referring to the action of the spirit of God. However, given the mythical undertones of the text and the fact that the wind was often associated with creation in the Ancient Near East (i.e. as blowing over the waters of the primeval flood), it can be argued that in Genesis 1:2 the senses of spirit-breath and wind are activated and that in this case the term רוח אלהים is an example of a case of polysemy, where all three senses are closely and non-trivially connected within the magicomythical cosmology of its time. That is, in contrast to our modern perception that these senses of the term are completely unrelated and should thus be viewed as alternative or separate senses.

\section{Conclusion}

In any one of the above contexts all three meanings of the רוח אלהים can make sense, but more so if one accepts that all three senses were activated at the same time. This would explain how humans and animals could receive their spirit by God's breath and the extraordinary creative force of the wind blowing over the primeval flood. The graphical description of God blowing through his nose and thus causing the waters of the sea to pile up also clearly implies that God's breath was perceived as causing an extraordinary wind to blow over these waters. At the most, one sense of the word may dominate in a specific context, but the other senses of the word are also activated. It is therefore completely unnecessary to engage in endless argument of which so-called alternative sense is relevant in a specific context when interpreting or translating the term רוח אלהים. - (20. -

Modern readers of the Bible should therefore be constantly made aware of the fact that their scientific cosmology differs significantly from the magico-mythical cosmology of the Bible and that this fact may result in their failure to recognise the polysemous nature of terms such as רוח אלהים, which may lead to a serious misinterpretation of the biblical text or a severe reduction in its meaning. In conclusion, it is important to point out that the purpose of this article was NOT merely to settle 'a small matter of translation', but served as an example to illustrate a larger hermeneutical problem, that is, when the biblical text is misinterpreted because the 'otherness' of the biblical text and its magicomythical cosmology are not sufficiently recognised (see Van Dyk 2017).

\section{Bible translations}

$\begin{array}{ll}\text { - } \mathrm{CEB} & \text { Common English Bible } \\ \text { - DRA } & \text { Douay-Rheims Bible, American Edition } \\ \text { - EXB } & \text { Expanded Bible } \\ \text { - JPS } & \text { Jewish Publication Society Bible } \\ \text { - KJV } & \text { King James Version } \\ \text { - NABRE } & \text { The New American Bible, Revised Edition, } \\ \text { - NAS } & \text { [Roman Catholic] } \\ \text { - NIV } & \text { New American Standard Bible } \\ \text { - NRSV } & \text { New Revised Standard Version } \\ \text { - NRSVA } & \text { New Revised Standard Version American } \\ \text { - OJB } & \text { Orthodox Jewish Bible } \\ \text { - RSV } & \text { Revised Standard Version } \\ \text { - VOICE } & \text { The Voice Bible }\end{array}$

\section{Acknowledgements Competing interests}

The author declares that he has no financial or personal relationships which may have inappropriately influenced him in writing this article. 


\section{References}

Albright, W.F., 1924, 'Contributions to biblical archaeology and philology', Journal for Biblical Literature 43, 363-369. https://doi.org/10.2307/3259267

Alter, R., 1996, Genesis. Translation and commentary, Norton, New York.

Barr, J., 2004, The semantics of biblical language, Wipf \& Stock, Eugene, OR.

Blenkinsopp, J., 2011, Creation, un-creation, re-creation: A discursive commentary on Genesis 1-11, T\&T Clark, New York.

Botterweck, G.J., Ringgren, H. \& Fabry, H.-J. (eds.), 2004, Theological dictionary of the Old Testament, vol. 13., transl. D.E. Green (Theological dictionary of the Old Testament), Eerdmans, Grand Rapids, MI.

Brown, F., Driver, S.R., Briggs, C.A., Strong, J. \& Gesenius, W., 2006, '끈,', in The Brown Driver-Briggs Hebrew and English lexicon: With an appendix containing the Biblical Aramaic, Hendricks Publishers, Peabody, MA.

Derrida, J. \& Bass, A., 2002, Writing and difference, University of Chicago Press, Chicago, IL.

Edwards, S., Makunga, N., Thwala, J. \& Nzima, D., 2006, 'African breathing and spiritual healing', Indilinga - African Journal of Indigenous Knowledge Systems 5(2), 135-143.

Falkum, I.L. \& Vicente, A., 2015, 'Polysemy: Current perspectives and approaches' Lingua 157, 1-16. https://doi.org/10.1016/j.lingua.2015.02.002

Fillmore, C.J. \& Atkins, B.T.S., 2000, 'Describing polysemy: The case of "crawl"', in Polysemy: Theoretical and computational approaches, pp. 91-110, Oxford University Press, Oxford.

Freedman, T., 1996, 'רוח אלהים - And a wind from God. Genesis 1:2', Jewish Bible Quarterly 24(1), 9-13.

Gadamer, H.-G., 1982, Truth and method, Crossroad, New York.

Gaster, T.H., 1981, Myth, legend, and custom in the Old Testament: A comparative study with chapters from Sir James G. Frazer's Folklore in the Old Testament, Smith, Gloucester, MA.

Gunkel, H., 1966, Genesis, 7. Aufl., Vandenhoeck \& Ruprecht, Göttingen.

Klutz, T. (ed.), 2003, Magic in the biblical world: From the rod of Aaron to the ring of Solomon, T \& T Clark International, London.

Köhler, L., Baumgartner, W. \& Stamm, J.J., 1996, The Hebrew and Aramaic lexicon of the Old Testament, revised ed., vol. 3, transl. M.E.J. Richardson, Brill, Leiden.

Kosko, B., 1994, Fuzzy thinking: New science of fuzzy logic, Flamingo, London.
Lambert, W.G., 2007, 'Enuma Elish (The Babylonian epic of creation)', in M.J. Geller \& M. Schipper (eds.), Imagining creation, pp. 15-59, Brill Academic Publishers, Leiden, viewed 15 May 2017, from http://www.etana.org/node/581

McClellan, W.H., 1934, 'The meaning of Ruach 'Elohim in Genesis 1, 2', Biblica 15, 517-527.

Moscati, S., 1947, 'The wind in biblical and Phoenician cosmogony', Journal for Biblical Literature 66, 305-310. https://doi.org/10.2307/3262586

Noegel, S.B., 1995, 'Wordplay and translation technique in the Septuagint of Job', Aula Orientalis 14, 33-44.

Olmsted, D., n.d., Mu'ulil (Enlil) and Sud (Ninlil) - Mesopotamian spirit powers, viewed 24 October 2016, from www.davidolmsted.net

Oosthuizen, G.C., 1967, The theology of a South African Messiah: An analysis of the hymnal of 'The Church of the Nazarites', Brill, Leiden.

Pickering, M., 1999, 'History as horizon: Gadamer, tradition and critique', Rethinking History 3, 177-195. https://doi.org/10.1080/13642529908596342

Skinner, J., 1930, A critical and exegetical commentary on Genesis, 2nd ed., T \& T Clark, Edinburgh.

Speiser, E.A., 1964, Genesis. Introduction, translation, and notes, Doubleday, Garden City, NY.

'The Story of Re', n.d., viewed 02 November 2016, from http://www.egyptianmyths. net/mythre.htm

Tylor, E.B., 2010, Primitive culture: Researches into the development of mythology, philosophy, religion, art, and custom, Cambridge University Press, Cambridge.

Van Dyk, P.J., 2017, 'When misinterpreting the bible becomes a habit', Unpublished article.

Van Selms, A., 1967, Genesis deel I, vol. 1, Callenbach, Nijkerk.

Vicente, A., 2015, 'The green leaves and the expert: Polysemy and truth-conditiona variability', Lingua 157, 54-65. https://doi.org/10.1016/j.lingua.2014.04.013

Von Rad, G., 1972, Genesis: A commentary, transl. J.H. Marks, Westminster Press, Philadelphia, PA.

Wallace, D.B., 2014, viewed 27 May 2017, from https://danielbwallace. com/2014/12/08/lexical-fallacies-by-linguists/

Walton, J.H., 2009, The lost world of Genesis one: Ancient cosmology and the origins debate, IVP Academic, Downers Grove, IL.

Westermann, C., 1976, Genesis 1-11, 2. Aufl., Teilbd. 1, Neukirchener Verlag, Neukirchen-Vluyn.

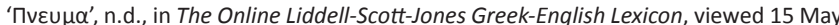
2017, from http://stephanus.tlg.uci.edu/lsj/\#eid=1\&context=ls 